\title{
HUNGAN TINGKAT PENGETAHUAN PEMELIHARAAN KESEHATAN GIGI DAN MULUT DENGAN PENDIDIKAN IBU HAMIL DI KABUPATEN GIANYAR TAHUN 2021
}

\author{
I Gusti Ayu Raiyanti ${ }^{1}$ I Nyoman Gejir ${ }^{2}$, Ni Kadek Devi Kastini ${ }^{3}$, \\ 1,2.Dosen Jurusan Kesehatan Gigi Poltekkes Denpasa. \\ ${ }^{3}$.Mahasiswa Jurusan Kesehatan Gigi Poltekkes Denpasar \\ Email: igaraiyanti@gmail.com
}

\begin{abstract}
ABTRACT
Phenomenon in the society found that $65 \%$ of pregnant women had four too risky in pregnancy, are too young, too old, too often and too much. Total parity is too much, meaning that more and more pregnant women will be at risk of adverse pregnancy outcomes obtained. It should be lowered with adequate prenatal care that is focused on the health and reduction in risk factors, so that the condition can improve the outcome of pregnancy (Indriyani, 2013). Based on theabove, it is necessary to find out the correlation between education and knowledge with the dental hygiene on women pregnant. The purpose of this study is identify the relationship between the level of education, knowledge with the pregnat in to describe the level of knowledge of dental and oral health care in respondens at the location of KKN IPE Health Polytechnic of the Ministry of Health Denpasar Group 4 Gianyar I, Gianyar Regency in 2021. Method: Type of the reseach was analytical research with cross sectional approach. Thepopulation of this research were all women in the pregnant as peoplewith sample size of 45 people. The independent variable was education and knowledge dental hygiene whereas the dependent variables were behavior Bivariat analysis used Correlation Rank Spearman Test. The The study design used is observational approach with cross sectional design. Samples were taken by accidental sampling with research instruments such as observation sheet with a sample of 45 pregnant women, level of education $(51,1 \%)$ is high school, Spearman's rho analysis of a significant relationship between the level of education and knowledge with the outcome $(\mathrm{p}=0,064,<0,05)$ There is a correlation between education with knowledge of dental hygiene (p-value $=0,046<0,05$ ). The Conclusion: There was a correlation between education and knowledge with dental hygiene
\end{abstract}

Keywords : Education, Knowledge, Pregnant women

\section{PENDAHULUAN}

Kehamilan dapat memiliki kondisi yang disebut resiko, baik resiko rendah sampai tinggi. Kehamilan resiko rendah merupakan kehamilan yang fisiologis, kemungkinan besar diikuti dengan persalinan normal serta ibu dan bayi sehat. Sementara kehamilan resiko tinggi adalah salah satu kehamilan yang didalamnya, kehidupan atau kesehatan ibu maupun janin dalam bahaya akibat gangguan kehamilan ${ }^{1}$ Ibu hamil merupakan salah satu kelompok yang rentan akan penyakit gigi dan mulut. Beberapa penelitian menyatakan bahwa tingkat pengetahuan 
dan perilaku ibu hamil dapat berpengaruh pada kesehatan gigi dan mulut.

Terdapat faktor-faktor yang mempengaruhi kehamilan resiko tinggi meliputi umur, pengetahuan , paritas, pendidikan, pekerjaan, status sosial ekonomi, dan sebagainya ${ }^{2}$.

Program pembangunan kesehatan di Negara Indonesia saat ini masih diprioritaskan pada upaya peningkatan derajat kesehatan ibu dan anak, terutama kelompok yang paling rentan kesehatan yaitu ibu hamil, ibu bersalin dan ibu nifas serta bayi pada masa perinatal.

\section{METODO PENELITIAN}

Desain penelitian yang digunakan adalah pendekatan Observasional dengan rancangan cross sectional yaitu dimana data Independen dan Dependen dikumpulkan dalam waktu yang bersama (point time approach) ${ }^{3}$ Penelitian ini dilakukan pada bulan Bulan Maret sampai April Tahun 2021. Penelitian ini dilakukan di lokasi KKN IPE Poltekkes Kemenkes Denpasar Kelompok 4 Gianyar I Kabupaten Gianyar. Sampel penelitian yaitu seluruh Ibu Hamil yang menjadi keluarga binaan pada saat KKN IPE Poltekkes Kemenkes Denpasar Kelompok 4 Gianyar I Kabupaten Gianyar Tahun 2021 yang berjumlah 45 orang

\section{HASIL PENELITIAN DAN PEMBAHASAN}

\section{Kondisi lokasi penelitian}

Kabupaten Gianyar merupakan salah satu kabupaten dari sembilan kabupaten/kota yang terdapat di Provinsi Bali. Kabupaten Gianyar terdiri dari tujuh kecamatan, 64 desa, enam kelurahan, 504 banjar/dusun. Kabupaten Gianyar memiliki luas wilayah $368 \mathrm{~km}^{2}$ atau sekitar $6,53 \%$ dari luas wilayah Provinsi Bali. Kecamatan Sukawati merupankan salah satu kecamatan di Kabupaten Gianyar dengan jumlah penduduk yaitu 122.698 jiwa dan luas wilayah $55,02 \mathrm{~km}^{2}$.

\section{Karakteristik subjek penelitian}

Karakteristik ibu hamil berdasarkan tingkat pendidikan di lokasi KKN IPE Poltekkes Kemenkes Denpasar Kelompok 4 Gianyar I Kabupaten Gianyar Tahun 2021 dapat dilihat pada gambar 2.

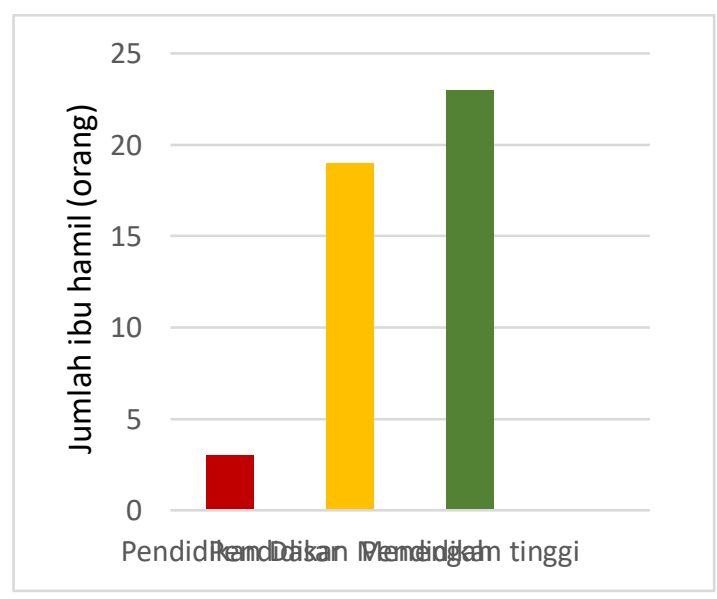

Gambar 2. Karakteristik Ibu Hamil 
Berdasarkan Tingkat Pendidikan di Lokasi KKN IPE Poltekkes Kemenkes Denpasar Kelompok 4 Gianyar I Kabupaten Gianyar Tahun 2021

Gambar 2 menunjukkan bahwa dari 45 responden yang diteliti paling banyak ibu hamil dengan pendidikan tinggi sebanyak 23 orang dan paling sedikit dengan pendidikan dasar sebanyak tiga orang. dengan kategori baik yaitu 27 orang $(60 \%)$ dan paling sedikit dengan kategori kurang yaitu tiga orang $(6,67 \%)$.

2.Persentase ibu hamil yang memiliki tingkat pengetahuan pemeliharaan kesehatan gigi dan mulut di lokasi $\mathrm{KKN}$ IPE Poltekkes Kemenkes Denpaar tahun 2021 berdasarkan tingkat pendidikan.

Tabel 2

Distribusi Persentase Tingkat Pengetahuan Pemeliharaan Kesehatan Gigi dan Mulut Ibu Hamil Berdasarkan Pendidikan

\section{2 . Hasil Penelitian}

Berdasarkan data diperoleh, distribusi tingkat pengetahuan tentang kesehatan gigi dan mulut berdasarkan $\begin{array}{llllllllll}1 & \text { Pendidikan Dasar } & 1 & 33,3 & 0 & 0 & 2 & 66,6 & 3 & 100\end{array}$ tingkat pendidikan

a. Analisis Univariat

$\begin{array}{llllllllll}2 & \text { Pendidikan } & 1 & 52,6 & 8 & 42,1 & 1 & 5,26 & 1 & 100\end{array}$

$\begin{array}{llllllllll}3 & \text { Pendidikan Tinggi } & 1 & 69,5 & 7 & 30,4 & 0 & 0 & 2 & 100\end{array}$

Tabel 1. Distribusi Tingkat Pengetahuan

Jumlah

$7 \quad 3$ Ibu HamilDistribusi Persentase Tingkat Pengetahuan Pemeliharaan Kesehatan Gigi dan Mulut Ibu Hamil

Tabel 1

Distribusi Persentase Tingkat Pengetahuan Pemeliharaan Kesehatan Gigi dan Mulut Ibu Hamil

\begin{tabular}{cccc}
\hline No & $\begin{array}{c}\text { Kategori } \\
\text { tingkat } \\
\text { pengetahuan }\end{array}$ & Frekuesi & $\begin{array}{c}\text { Persen } \\
\text { tase } \\
(\%)\end{array}$ \\
\hline 1 & Baik & 27 & 60 \\
2 & Cukup & 15 & 33,33 \\
3 & Kurang & 3 & 6,67 \\
\hline & Jumlah & 45 & 100 \\
\hline
\end{tabular}

Tabel 1 menunjukkan bahwa dari $45 \mathrm{ibu}$ hamil, persentase tingkat pengetahuan ibu hamil paling banyak
Tabel 2. menunjukkan bahwa dari 45 ibu hamil, persentase tingkat pengetahuan berdasarkan tingkat pendidikan paling banyak yaitu pendidikan tinggi dengan kategori baik sebanyak 16 orang $(69,57 \%)$ dan tidak ada ibu hamil yang memiliki tingkat pendidikan dasar dengan kategori cukup (0\%) dan pendidikan tinggi dengan kategori kurang $(0 \%)$.

Rata - rata tingkat pengetahuan tentang pemeliharaan kesehatan gigi dan 
mulut pada ibu hamil di lokasi KKN IPE Poltekkes Kemenkes Denpasar Kelompok 4 Gianyar I Kabupaten Gianyar Tahun 2021 adalah 78,44 dengan kategori cukup.

\section{b.Analisis Bivariat}

Hubungan pendidikan dengan pengetahuan dengan menggunakan uji korelasi rank spearman pada hubungan pendidikan dengan pengetahuan, didapatkan hasil koefisien korelasi $\mathrm{r}=$ 0,064 yang artinya mempunyai hubungan rendah dengan arah hubungan positif sehingga dapat diartikan pula semakin tinggi pendidikan maka semakin tinggi pengetahuan ibu hamil tentang kesehatan gigi dan mulut Hasil uji statistik korelasi menunjukan bahwa $\mathrm{p}$-value $=0,064$ $(<0,05)$ sehingga dapat disimpulkan ada hubungan yang signifikan antara pendidikan dengan pengetahuan mengenai kesehatan gigi dan mulut pada ibu hamil.

\section{B.Pembahasan}

Berdasarkan hasil penelitian terhadap 45 ibu hamil di lokasi KKN IPE Poltekkes Kemenkes Denpasar Kelompok 4 Gianyar I Kabupaten Gianyar Tahun 2021, diketahui bahwa persentase ibu hamil yang memiliki tingkat pengetahuan pemeliharaan kesehatan gigi dan mulut paling banyak berada pada kategori baik yaitu 27 orang ibu hamil (60\%). Hasil penelitian ini sejalan dengan penelitian yang dilakukan oleh Setyawati di Puskesmas Dlingo II Yogyakarta, bahwa sebagian besar pengetahuan kesehatan gigi dan mulut ibu hamil adalah baik yaitu sebanyak 38 responden atau $84.4 \%$ dari 45 responden. ${ }^{5}$ Kemungkinan hal ini disebabkan kerena responden sudah pernah mendapatkan informasi mengenai pemeliharaan kesehatan gigi dan mulut pada saat pelaksanaan KKN IPE Poltekkes Kemenkes Denpasar saat diberikan penyuluhan oleh mahasiswa, JKG pada waktu pelaksanaan IPE sehingga pengetahuan yang dimiliki ibu hamil saat ini paling banyak pada kategori baik.

Pendapat ini didukung oleh pernyataan Mubarak yang menyebutkan bahwa informasi merupakan salah satu faktor yang dapat mempengaruhi pengetahuan seseorang. Informasi dapat membantu mempercepat seseorang untuk memperoleh pengetahuan. ${ }^{6}$ Pendapat ini didukung pula oleh pernyatan Mubarak yang menyatakan bahwa semakin tinggi pendidikan seseorang semakin mudah mereka menerima informasi, sehingga semakin banyak informasi yang mereka dapatkan, dan pada akhirnya semakin banyak pengetahuan yang dimilikinya. ${ }^{6}$ Berdasarkan tingkat pendidikan menunjukkan bahwa persentase ibu hamil paling banyak yaitu pendidikan tinggi 
dengan kategori baik sebanyak 16 orang $(69,57 \%)$. Kemungkinan hal ini disebabkan karena pendidikan merupakan salah satu faktor yang dapat mempengaruhi tingkat pengetahuan seseorang, semakin tinggi pendidikan seseorang maka semakin baik pengetahuan yang dimiliki 7 Pendidikan berarti bimbingan yang diberikan oleh seseorang terhadap perkembangan orang lain menuju ke arah suatu cita.cita tertentu. Makin tinggi tingkat pendidikan seseorang, maka makin mudah dalam memperoleh menerima informasi, sehingga kemampuan ibu dalam berpikir lebih rasional. Ibu yang mempunyai pendidikan tinggi akan lebih berpikir rasional ${ }^{8}$

Pendidikan ibu sangat mempengaruhi bagaimana seseorang untuk bertindak dan mencari penyebab serta solusi dalam hidupnya. Orang yang berpendidikan tinggi biasanya akan bertindak lebih rasional ${ }^{9}$ Hasil penelitian oleh Dictionary of Education menyebutkan bahwa pendidikan adalah proses dimana seseorang mengembangkan kemampuan sikap dan bentuk-bentuk tingkah laku lainnya

$$
\text { Rata - rata pengetahuan }
$$
tentang pemeliharaan kesehatan gigi dan mulut pada ibu hamil di lokasi KKN IPE Poltekkes Kemenkes Denpasar Kelompok 4 Gianyar I Kabupaten Gianyar Tahun 2021 dengan kategori cukup yaitu 78,44.
Hasil penelitian ini sejalan dengan penelitian Yulianti di Puskesmas pembantu Dauh Puri Denpasar Barat terhadap 30 orang ibu hamil dimana didapat rata - rata pengetahuan ibu hamil dengan kategori cukup yaitu $72,6 .{ }^{10} \mathrm{Hal}$ ini kemungkinan disebabkan karena tingkat pendidikan responden yang bervariasi, ada responden yang memiliki tingkat pendidikan dasar yaitu SD, tingkat pendidikan menengah yaitu SMA, dan tingkat pendidikan tinggi yaitu diploma dan sarjana yang dapat mempengaruhi responden dalam menerima informasi mengenai pemeliharaan kesehatan gigi dan mulut. Tingkat pendidikan merupakan faktor yang mendasari pengambilan keputusan dan juga ditunjang oleh tingkat pengetahuan ibu tentang kesehatan, lingkungan, ekonomi, interaksi dengan tenaga kesehatan dan kesadaran ibu itu sendiri. Terdapat juga beberapa ibu hamil yang sudah memiliki pengetahuan yang cukup baru akan memeriksakan kesehatan gigi dan mulut jika yang sangat mengganggu. Pendidikan adalah suatu proses belajar yang berarti dalam pendidikan itu terjadi proses pertumbuhan, perkembangan, atau perubahan kearah yang lebih dewasa. Kondisi pendidikan merupakan salah satu indikator yang kerap ditelaah dalam mengukur tingkat pembangunan manusia suatu negara. Melalui pengetahuan, pendidikan 
berkontribusi terhadap perubahan perilaku kesehatan. Pengetahuan yang dipengaruhi oleh tingkat pendidikan merupakan salah satu faktor pencetus yang berperan dalam mempengaruhi keputusan seseorang untuk berprilaku sehat.${ }^{10}$ Pendidikan berarti bimbingan yang diberikan seseorang pada orang lain terhadap sesuatu hal agar mereka dapat memahami. Tidak dapat dipungkiri bahwa makin tinggi pendidikan seseorang semakin mudah pula mereka menerima informasi dan pada akhirnya makin banyak pula pengetahuan yang dimilikinya.Sebaliknya jika seseorang tingkat pendidikannya rendah, akan menghambat perkembangan sikap seseorang terhadap penerimaan informasi dan nilai-nilai yang baru diperkenalkan. Dengan demikian semakin tinggi tingkat pendidikan ibu semakin mudah ibu untuk memperoleh informasi. Dari hasil uji korelasi Spearman terdapat hubungan antara tingkat pendidikan dengan tingkat pengetahuan kesehatan gigi dan mulut 0,064 menunjukan bahwa $\mathrm{p}$-value $=0,064$ $(<0,05)$ yang artinya mempunyai hubungan dengan arah hubungan positif sehingga dapat diartikan pula semakin tinggi pendidikan maka semakin tinggi pengetahuan ibu hamil tentang kesehatan gigi dan mulut Hasil uji statistik korelasi sehingga dapat disimpulkan ada hubungan yang signifikan antara pendidikan dengan pengetahuan mengenai kesehatan gigi dan mulut pada ibu hamil. Adanya hubungan antara tingkat pendidikan dengan tingkat pengetahuan karena tidak dapat dipungkiri bahwa makin tinggi pendidikan seseorang semakin tinggi pula mereka menerima informasi dan pada akhirnya makin banyak pula pengetahuan yangdimilikinya. Sebaliknya jika seseorang tingkat pendidikannya rendah, akan menghambat perkembangan sikap seseorang terhadap penerimaan informasi dan nilai-nilai yang baru diperkenalkan. Hasil penelitian yang dilakukan oleh Purwati bahwa tingkat pengetahuan yang dipenga-ruhi oleh pendidikan, untuk tingkat pendidikan yang lebih tinggi maka tingkat pengetahuannya juga lebih baik. ${ }^{11}$

\section{Daftar Pustaka:}

1. Indriyani D. (2013). Keperawatan maternitas Pada Area Perawatan Antenatal, Graha Ilmu, Yogyakarta.

2. Sofian A. (2013). Rustam Mochtar Sinopsis Obstetri: Obstetri Operatif, Obstetri Sosial, Ed. 3. Jilid 2. Penerbit Buku Kedokteran EGC, Jakarta.

\section{Notoatmojo 2012). Metodologi Penelitian Kesehatan / Soekidjo Notoadmojo - Ed Rev . Jakarta: Rineka Cipta}

4. Dinkes Kabupaten Gianyar. 2019. Profil Kesehatan Kabupaten Gianyar Tahun 2019. Tersedia dalam file:///D:/Devi/KTI/KTI\%20DEVI/pr ofil $\% 202020 \% 20$ dinas\%20kesehatan \%20kab.\%20gianyar.pdf. Diakses pada tanggal 03 Maret 2021. 
5. Setyawati N1, Suherni2, Nur Djanah3

Poltekkes Kemenkes Yogyakarta hubungan antara tingkat pengetahuan dengan perilaku kesehatan gigi dan mulut ibu hamil di Puskesmas Dlingo II tahun 2017 http://ejournalpoltekkes

Yogya.ac.id/index.php/HM/article/do wnload $/ 35 / 37 /$. Diakses pada tanggal 26 Januari 2021.

6.Mubarak, W.I., Chayatin, N., Rozikin, K., Supradi. 2007. Promosi Kesehatan Sebuah Pengantar Proses Belajar Mengajar dalam Pendidikan. Yogyakarata: Graha Ilmu.

7. Notoatmodjo,S. 2003. Ilmu Kesehatan Masyarakat Prinsip-Prinsip Dasar.J akarta: Rineka Cipta.

8 Ferry, A., dan J. Angeline. 2018. Bebas Sakit Gigi \& Mulut Pada Kehamilan. Yogyakarta: Rapha Publishing.

9. Walyani E.S. (2015). Asuhan Kebidanan Pada Kehamilan, PUSTAKABARUPRESS, Yogyakarta.

10. Kemenkes RI. 2013. Hasil Riset Kesehatan Dasar 2013. Jakarta : Kepala Badan Penelitian dan Pengembangan Kesehatan Kementerian Kesehatan RI.

11. Purwati, W. 2013. TingkatPengetahuan Tentang Kesehatan Gigi dan Mulut Guru Penjaskes SD di Kecamatan Rendang Tahun 2013. 